IZA DP No. 8294

Recovery Performance of Primary Agriculture Credit Societies in India: An Assessment

Rabin Mazumder

Chandrasekhar Chakravarty

Amit K. Bhandari

June 2014 


\title{
Recovery Performance of Primary Agriculture Credit Societies in India: An Assessment
}

\author{
Rabin Mazumder \\ Army Institute of Management, India \\ Chandrasekhar Chakravarty \\ Asia e University, India \\ Amit K. Bhandari \\ RBC Evening College, \\ KIARTD and IZA \\ Discussion Paper No. 8294 \\ June 2014 \\ IZA \\ P.O. Box 7240 \\ 53072 Bonn \\ Germany \\ Phone: +49-228-3894-0 \\ Fax: +49-228-3894-180 \\ E-mail: iza@iza.org
}

Any opinions expressed here are those of the author(s) and not those of IZA. Research published in this series may include views on policy, but the institute itself takes no institutional policy positions. The IZA research network is committed to the IZA Guiding Principles of Research Integrity.

The Institute for the Study of Labor (IZA) in Bonn is a local and virtual international research center and a place of communication between science, politics and business. IZA is an independent nonprofit organization supported by Deutsche Post Foundation. The center is associated with the University of Bonn and offers a stimulating research environment through its international network, workshops and conferences, data service, project support, research visits and doctoral program. IZA engages in (i) original and internationally competitive research in all fields of labor economics, (ii) development of policy concepts, and (iii) dissemination of research results and concepts to the interested public.

IZA Discussion Papers often represent preliminary work and are circulated to encourage discussion. Citation of such a paper should account for its provisional character. A revised version may be available directly from the author. 


\title{
ABSTRACT \\ Recovery Performance of Primary Agriculture Credit Societies in India: An Assessment
}

\begin{abstract}
Agricultural credit is one of the most crucial inputs in all agricultural development programmes. Access of rural credit has still remained scarce in India. Primary Agriculture Credit Societies (PACS) working at grass-root level, having direct contact with the rural people and meet their financial requirements. The problem of loan overdue is a serious concern in different regions of the country, as it affects the recycling of funds and loses its economic viability as a lending institution. The present study examines the recovery performance of rural credit given by PACS in six different regions of India namely Central, Northern, Southern, Eastern, North-East and Western. The result suggests that the performance of credit recovery has been low in north-eastern states and high in northern and southern states. Recovery performance of credit is directly proportional to non-agricultural loan to agricultural loan, trained-untrained staff ratio and average member per society and inversely related with proportion of government capital to working capital and real growth rates at constant price. To make all PACS viable and ensure adequate and timely flow of credit, appropriate policies are required from the Reserve Bank of India in collaboration with State Governments.
\end{abstract}

JEL Classification: E61, F34, G21, Q13

Keywords: cooperative, credit, loan overdue, recovery, policy

Corresponding author:

Amit K. Bhandari

Rishi Bankim Chandra College

Department of Economics

Naihati - 7431645

India

E-mail: amitbhandari2@rediffmail.com 


\section{Introduction}

Agriculture forms the backbone of the Indian economy and can also largely stand for the prosperity of the Indian economy. According to Census 2011, about 68.8 percent people lives in rural area and their livelihood depends on agriculture either directly or indirectly. The share of agriculture and its allied sectors in the gross domestic product (GDP) has come down to 14 percent in 2011-12 (at 2004-05 prices). The sector has got potential to achieve higher growth rates and also be an engine of growth, so that growth in other sectors and overall growth rate of the economy can be achieved.

Agriculture is an unorganized profession. Its success and failure depends, to a large extent, on climatic factors. Further, it is not always possible to distinguish between productive and unproductive loans of the farmers. Because of these factors, banks did not show much interest in advancing loans to agriculture and allied activities for a long time and farmers were forced to depend on moneylenders and mahajans. Agricultural credit is one of the most crucial inputs in all agricultural development programmes. Since independence, a multi agency approach consisting of cooperatives, commercial banks and regional rural banks-known as institutional credit has been adopted to provide cheaper and adequate credit to farmers.

Farmers need funds for short periods of less than 15 months for the purpose of cultivation or for meeting domestic expenses. With this fund they purchase seeds, fertilizers, fodder for cattle and other inputs related to agriculture. They may require funds to support their families in those years when the crops have not been good or adequate for the purpose. Such short period loans are normally repaid after the harvest. The main agents for granting short term loans are the moneylenders and cooperative societies. Medium term loans are generally obtained for the purchase of cattle, small agricultural implements, etc. The period for such loans extends from 15 months to 5 years. These loans are generally provided by money lenders, relatives of farmers, cooperative societies and commercial banks. The farmers need finances for the purpose of buying additional land, to make permanent improvement on land, to pay off old debt and to purchase costly agriculture machinery. These loans are for long periods of more than 5 years.

In the field of cooperation, the Primary Agricultural Credit Societies (PACS) provide mainly short term and medium term loans. Since, PACS perform at grass-root level, have direct contact with the rural people and meet the financial requirements of more than 121 million members in 
2010-11. Our study is based on recovery performance of PACS in six different regions of the country.

The cooperative movement has been in existence for more than a century. According to several critics, the movement is an utter failure and that it should be scrapped because it failed to abolish poverty of the rural masses and unable to increase agricultural production. The utter irrelevance of the cooperative movement was indicated by the fact that in 1954 (exactly after 50 years of its existence) the cooperative institutions supplied just 3 percent of the credit requirements of the farmers. It was true that the movement was not much of a success before 1954, but since then, with the Government and Reserve Bank taking active interest, the movement has made great progress. The problem of loan overdue is matter of serious concern, as it affects the recycling of funds and credit expansion on the one hand and economic viability of the lending institutions, specially the cooperatives and the Regional Rural Banks, on the other. Agricultural credit and recovery should go hand in hand. These two aspects are interlinked, mutually dependent and indivisible. Hence, the credit service embraces loan advancement along with its recovery in time. Performance of the loan recovery is considered as an index of evaluating the operational efficiency and organizational proficiency of a financing institution. Recovery of loans in time reinforces the resource position of cooperatives. Therefore, its borrowing power from financing institutions has been accelerated and the society enables to advance maximum amount of loans to its members. Thus, not only the confidence level of members of the society boosts up but it also improves morale and awareness among members. Conversely, poor recovery increases the number of defaulters and over dues which in turn reduces borrowing power consequently. Ultimately, there is a stiff downfall in the turnover of loans. If prolong over dues of PACS to the financing institutions surpass specific proportion of demand then it is unable to get funds and consequently makes no fresh loans to the members of the society. As a result, those members are willing and capable to repay do not do so, because they suspect about getting fresh loan. This intensifies overdue position. Therefore, recovery of loans in time has a great impact on the sound functioning of PACS. It is found that uneven distribution of cooperative benefits and considerable disparities in credit availability between different regions fade the cooperative credit movement. The most outstanding of the weaknesses, which indeed is at the root of many of the shortfalls in the cooperative programme, is the significant differences of recovery performance in different regions. 
The present study investigates the extent of regional disparity in recovery performance of rural credit from the primary agricultural cooperative credit societies in India. The rest of the paper is organized as follows. In section 2, literature review of the study is presented. This is followed by the research objectives and methodology in the subsequent sections 3 and 4 respectively. This followed by discussion of results in section 5 . In the concluding section, we discuss the major findings of the study.

\section{Literature Review}

Cooperative movement in India was initiated in 1904 through the establishment of cooperative credit societies. These societies were organized to relieve the indebtedness of rural people and promote thrift. There have been many research studies and committee/working group reported on the rural credit system in India. Committees have been set up both in the pre-independence and post-independence periods. Royal Commission on Agriculture (1928) has reaffirmed that from the point of view of structural appropriateness, there is no alternative to cooperatives at the village level for provision of rural credit.

Dandekar and Wadia (1989) pointed out that intervention of external forces such as loan waivers, concession in various forms towards repayment of principal and payment of interest which had also affected the recovery performance of credit institutions to a significant extent.

The study of Velayudham and Sankarnarayanan (1990) found that recovery position of Regional Rural Banks were bad. Their recovery varied between 51 - 61 percent. Thus, overdue have varied between 39 - 49 percent. The high incidence of overdue is attributable to a number of internal and external factors. The internal factors include the defective loaning policies, weak monitoring and supervision, apathy towards recovery, failure to link lending with development and to ensure proper end use of the loan. Among the external factors mention may be made of political interference, willful default, droughts and floods, lack of legal and administrative support from the State government in the matter of loan recovery.

According to Agarwal, Puhazhendhi and Satyasai (1997), the worst implication of build-up of overdue is that a large number of farmers who are still outside the purview of institutional credit suffer on account of non-availability of credit. 
In the article of "Restructuring Rural Credit Cooperative Institutions" by Satyasai and Badatya (2000) it has been mentioned that many non-official workers may not be aware of, that government is not a net lender, but a net borrower from the cooperatives.

Reserve Bank of India (Mumbai, 2002) reported that rural cooperative institutions have a high level of NPAs (non-performing assets). At the end of March 2001, the aggregate NPAs of State Cooperative Banks were estimated at 3,889 crore which was 13.0 percent of the total outstanding loans and advance. Nearly three-fifth of the gross NPAs consisted of substandard assets and more than one-third were doubtful assets.

Research study of Misra (2009) identified that the factors which may have led to the unstable financial condition of the PACS. The inferences drawn from the study was that the government contribution to the share capital of the cooperatives adversely affects the recovery performance. It also found that, larger membership size has a negative effect on recovery performance. Again it was established that there is an inverse relationship between higher proportion of nonborrowing members and recovery performance.

So far, many committees have recommended for improving the financial condition of the cooperatives, but it did not work. The possible reason for this could be the gap between the recommendations and their actual implementation. Although, number of studies which have already been made on Indian cooperative sectors plus analysis had been done on State level recovery performance yet none of the study has been done on regional level recovery performance. Hence, in this study, we shall focus on the comparative analysis of recover performance of credit in six different regions in India.

\section{Research Objectives}

i. To assess the regional disparity in the recovery performance of agricultural credit by PACS in India.

ii. To identify the determinants of regional disparity in the recovery performance of agricultural credit and its effect. 


\section{Methodology}

For the present study is based on data from the secondary sources. The data on agricultural credit of PACS of different regions were collected from the following sources.

1. National Federation of State Cooperative Banks Ltd.

2. Report of the Expert Committee of NABARD to Examine Three Tier Short Term Cooperative Credit Structure.

The regional disparity and the determinants of regional disparity in the recovery performance of agricultural credit of PACS were analyzed across six regions in India namely Central, Eastern, Northern, North-East, Southern and Western region. The analysis is carried out by taking the time period from 2002-03 to 2010-11. All the states and the union territories were included in the analysis irrespective of the time period.

Six regions are purposively selected for the study. The list of states and union territories is presented below:

Central region: Delhi, Madhya Pradesh, Uttar Pradesh, Chattisgarh and Uttarakhand.

Eastern region: Bihar, Jharkhand, Orissa, West Bengal and Andaman \& Nicobar.

Northern region: Haryana, Himachal Pradesh, Jammu and Kashmir, Punjab, Rajasthan and Chandigarh.

North-East region: Assam, Arunachal Pradesh, Manipur, Meghalaya, Mizoram, Nagaland, Tripura, Sikkim.

Southern region: Andhra Pradesh, Karnataka, Kerala, Pondicherry, Tamil Nadu, Dadra and Nagar Haweli.

Western region: Gujarat, Goa, Maharashtra and Daman \& Diu.

In the second stage, five factors were selected purposively which are having the mixed bag of impact in different regions in terms of recovery performance. These factors are (a) nonagricultural loan proportion to agricultural loan, (b) government capital proportion to working capital, (c) trained- untrained staff ratio, (d) real growth rates at constant prices and (e) average members per society. The study made an attempt to identify the factors which contribute to the 
region wise variation of recovery performance of the PACS. The rationales behind selecting these factors are as follows.

(a) Non- agricultural loan proportion to agricultural loan: The PACS grants loans not only for agricultural operations but also grant non-agricultural loan to help the farmers in meeting all their credit requirements. It is essential from farmers' point of view otherwise; PACS would not have received full loyalty of the farmers. In this study, we required to find out whether a high proportion of non-agricultural loan to agricultural loan is accountable for deterioration of the recovery performance between the regions.

(b) Government capital proportion to working capital: The power which vest in the government under the cooperative law and rules are all -pervasive. Over the years, State has come to gain almost total financial and administrative control over the cooperatives, in the process stifling their growth. Instead of strengthening the base, a weak base was vastly expanded. The driving principle seemed to be: 'If people cannot or will not do it, the State can and will do it'. As a result, the cooperatives have virtually become 'government-directed, government-controlled and government-regulated enterprises' giving rise to red-tapism and administrative interference by the government in the day to day working of the cooperatives. More serious consequences of this 'politicization' of cooperative societies are interference in recovery of cooperative dues or promise to write off dues if elected to power, and determination of interest rates on considerations other than financial returns. Such actions generate a general psychology of non-repayment, vitiating the recovery climate and jeopardizing the financial interest of credit agencies. Here, we wanted to know the significance of government's involvement across the six regions.

(c) Trained- untrained staff ratio: Non- availability of competent and trained staff in different regions of PACS posed serious problems of credit repayment.

(d) Real growth rates at constant prices: Variation in the real growth rates at constant prices may have significant impact on recovery performance across the regions. Lack of growth reduces the volume of trade and subsequently the level of unemployment increases.

(e) Average members per society: Many PACS suffer from poor management and lack of enthusiasm and dedication among members resulting in a great deal of inefficiency and 
poor service to the members. In the study we sought to be answered the impacts of membership size and the mix of loan portfolio on the performance of the PACS across the regions.

An analysis of variance (ANOVA) is used to test the significant differences among sample means. It analyses different components of total variance of the sample to estimate the relative magnitude of within group variance due to uncontrolled random factors and between group variance which may have been influenced by the induction of independent variance.

\section{Research Hypotheses:}

For the purpose of this study, the following hypotheses were developed:

Section 1: Hypotheses regarding recovery performance of credit in different regions and years.

$\mathrm{H}_{1}$ : There is a significant difference in terms of recovery performance of credit in different regions.

$\mathrm{H}_{2}$ : There is a significant difference in terms of recovery performance of credit in different financial year.

\section{Section 2: Hypotheses regarding the different factors in different regions.}

$\mathrm{H}_{3}$ : There is a significant difference between the regions in terms of proportion of non agricultural loan to agricultural loan

$\mathrm{H}_{4}$ : There is a significant difference between the regions in terms of proportion of government capital to working capital.

$\mathrm{H}_{5}$ : There is a significant difference between the regions in terms of trained- untrained staff ratio. $\mathrm{H}_{6}$ : There is a significant difference between the regions in terms of real growth rates at constant prices.

$\mathrm{H}_{7}$ : There is a significant difference between the regions in terms of average member per society. 


\section{Discussion of Results}

Table 1: Descriptive Statistics on Recovery Performance of Credit in Different Years and Regions

\begin{tabular}{|c|c|c|c|c|c|c|}
\hline SUMMARY & Count & Sum & Average & Variance & $\begin{array}{l}\text { Standard } \\
\text { Deviation }\end{array}$ & $\begin{array}{c}\text { Coefficient } \\
\text { of } \\
\text { Variation }\end{array}$ \\
\hline $2002-2003$ & 6 & 353.06 & 58.84 & 85.94 & 9.27 & 15.75 \\
\hline 2003-2004 & 6 & 360.87 & 60.14 & 90.57 & 9.51 & 15.82 \\
\hline 2004-2005 & 6 & 371.62 & 61.93 & 107.25 & 10.35 & 16.72 \\
\hline 2005-2006 & 6 & 383.53 & 63.92 & 107.33 & 10.36 & 16.20 \\
\hline 2006-2007 & 6 & 390.41 & 65.06 & 120.50 & 10.97 & 16.87 \\
\hline $2007-2008$ & 6 & 362.85 & 60.47 & 75.46 & 8.68 & 14.36 \\
\hline 2008-2009 & 6 & 331.42 & 55.23 & 437.95 & 20.92 & 37.88 \\
\hline $2009-2010$ & 6 & 322.6 & 53.76 & 631.70 & 25.13 & 46.74 \\
\hline $2010-2011$ & 6 & 363.84 & 60.64 & 586.86 & 24.22 & 39.94 \\
\hline \multicolumn{7}{|c|}{ Region wise Descriptive Statistics } \\
\hline Central & 9 & 521.03 & 57.89 & 10.40 & 3.22 & 5.57 \\
\hline Eastern & 9 & 594.51 & 66.05 & 7.33 & 2.70 & 4.10 \\
\hline Northern & 9 & 661.69 & 73.52 & 17.70 & 4.20 & 5.72 \\
\hline North East & 9 & 349.03 & 38.78 & 218.66 & 14.78 & 38.12 \\
\hline Southern & 9 & 649.34 & 72.14 & 51.86 & 7.20 & 9.98 \\
\hline Western & 9 & 464.6 & 51.62 & 174.08 & 13.19 & 25.55 \\
\hline
\end{tabular}

Source: National Federation of State Cooperative Banks Ltd. Compilation by the authors 
Figure 1: Trend of Recovery Performance of Credit in Six Regions

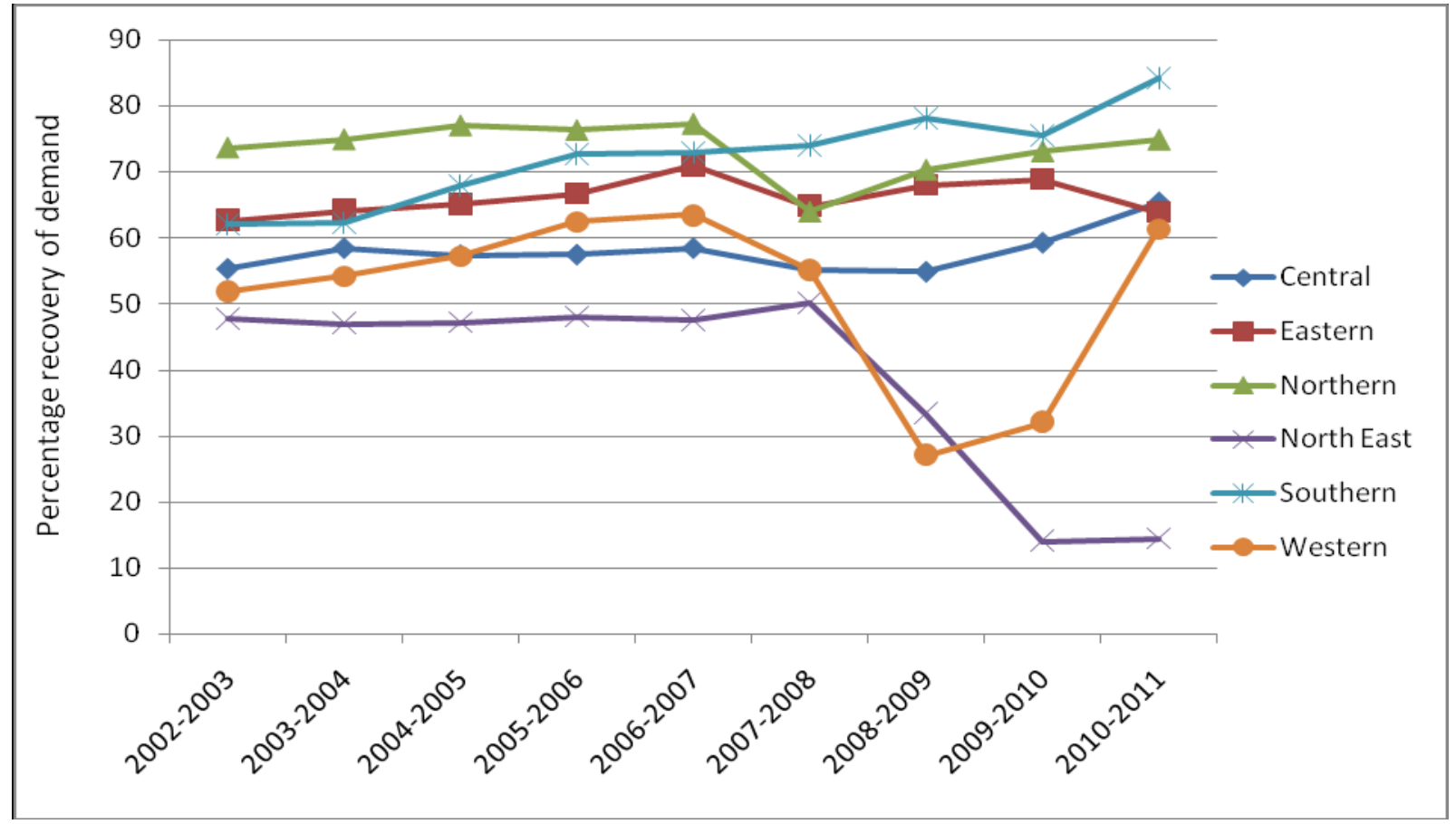

Table 2: ANOVA on Recovery Performance of Credit in Different Regions and Years

\begin{tabular}{|l|c|c|c|c|c|c|}
\hline $\begin{array}{l}\text { Source of } \\
\text { Variation }\end{array}$ & $\begin{array}{c}\text { Sum of } \\
\text { Squares } \\
\text { (SS) }\end{array}$ & $\begin{array}{c}\text { Degrees of } \\
\text { Freedom } \\
(\boldsymbol{d} f)\end{array}$ & $\begin{array}{c}\text { Mean Sum } \\
\text { of Squares } \\
\text { (MSS) }\end{array}$ & $\begin{array}{c}\boldsymbol{F} \\
\text { (Calculated) }\end{array}$ & $\begin{array}{c}\text { P- } \\
\text { value }\end{array}$ & $\begin{array}{c}\text { F } \\
\text { (Tabulated) }\end{array}$ \\
\hline Between & 650.13 & 8 & 81.26 & 1.01 & 0.43 & 2.18 \\
\hline Bears & 8027.73 & 5 & 1605.54 & 20.13 & 0.00 & 2.44 \\
Regions & 3190.33 & 40 & 79.75 & & & \\
\hline Error & 11868.2 & 53 & & & & \\
\hline Total & & & & & & \\
\hline
\end{tabular}

Source: Author's Research

From Table 1 it shows that the average recovery rate in northern region (73.52\%) is maximum compared to that of other five regions whereas the performance level of the north-east region is 
at its lowest level (38.78\%). As recovery performance level is concerned, eastern region shows high level of consistency (Coefficient of Variation $=4.10$ ) and then come the central region (Coefficient of Variation $=5.57$ ) and the northern region (Coefficient of Variation $=5.72$ ). On the other hand, north-east region shows high variability (Coefficient of Variation $=38.13$ ) in recovery performance. From the graph, it is comprehensible that the southern region is showing steady upward progress in recovery performance (Average recovery rate is $72.15 \%$ ) and the performance of north-east till 2007-2008 was in steady state level but after that, there is a sharp fall in the two consecutive years 2008-2009 and 2009-2010. The gap between the lines indicates the difference in recovery percentage. Comparing with northern and southern region (the average recovery performance apparently looks same in both regions) the former one has started with high level of recovery rate than the later one with its steady recovery till 2006-2007 and then downfall helped progressive southern region to surmount it.

In Table 2, variation in the performance of percentage recovery of demand in different regions has been reflected through ANOVA. With calculated values of F, given in the table, we can derive inferences as follows:

(i) Since the calculated value of $\mathrm{F}$ (20.13) is greater than 2.45, the tabulated value of $\mathrm{F}$ at $5 \%$ level of significance and 5, 40 degrees of freedom (d.f.), it is concluded that there is a significant difference in terms of recovery performance of credit in different regions. This proves the hypothesis $\mathrm{H}_{1}$.

(ii) Since the calculated value of F (1.02) is less than 2.18, the tabulated value of $F$ at $5 \%$ level of significance and 8, 40 d.f., it is concluded that there is no significant difference between financial years in terms of recovery performance of credit. Therefore, the hypothesis $\mathrm{H}_{2}$ rejected. 
Table 3: ANOVA on Different Factors in Different Regions

\begin{tabular}{|c|c|c|c|c|c|c|}
\hline $\begin{array}{l}\text { Source of } \\
\text { Variation }\end{array}$ & $\begin{array}{l}\text { Sum of } \\
\text { Squares } \\
\quad(S S)\end{array}$ & $\begin{array}{l}\text { Degrees } \\
\text { of } \\
\text { Freedom } \\
\text { (df) }\end{array}$ & $\begin{array}{l}\text { Mean } \\
\text { Sum of } \\
\text { Squares } \\
\text { (MSS) }\end{array}$ & $\begin{array}{c}F \\
\text { (Calculated) }\end{array}$ & P-value & $\begin{array}{c}F \\
\text { (Tabulated) }\end{array}$ \\
\hline $\begin{array}{l}\text { Between Regions } \\
\text { (Proportion of } \\
\text { non agricultural } \\
\text { loan to } \\
\text { agricultural loan) }\end{array}$ & 25861.49 & 5 & 5172.29 & 21.06 & 2.9E-10 & 2.44 \\
\hline $\begin{array}{l}\text { Between Regions } \\
\text { (Proportion of } \\
\text { government } \\
\text { capital to } \\
\text { working capital) } \\
\end{array}$ & 188.23 & 5 & 37.64 & 137.83 & $4.14 \mathrm{E}-24$ & 2.44 \\
\hline $\begin{array}{l}\text { Between Regions } \\
\text { (Trained- } \\
\text { untrained staff } \\
\text { ratio) }\end{array}$ & 22075.82 & 5 & 4415.16 & 4.28 & 0.003247 & 2.44 \\
\hline $\begin{array}{l}\text { Between Regions } \\
\text { (Real growth } \\
\text { rates at constant } \\
\text { prices) }\end{array}$ & 22.00 & 5 & 4.40 & 0.94 & 0.465754 & 2.44 \\
\hline $\begin{array}{l}\text { Between Regions } \\
\text { (Average } \\
\text { member per } \\
\text { society) }\end{array}$ & 47.31 & 5 & 9.46 & 159.54 & 2.61E-25 & 2.44 \\
\hline
\end{tabular}

Source: Author's calculation

In Table 3, ANOVA on different factors in different regions has been projected. The proportion of non agricultural loan to agricultural loan with calculated value of $F$ (21.07) is greater than 2.45, the tabulated value of $\mathrm{F}$ at 5\% level of significance and 5, 40 d.f., it is concluded that there is a significant difference between the regions in terms of proportion of non agricultural loan to agricultural loan. This proves hypothesis $\mathrm{H}_{3}$.

The proportion of government capital to working capital with calculated value of $F(137.84)$ is greater than 2.45, the tabulated value of $\mathrm{F}$ at 5\% level of significance and 5, 40 d.f., it is said that there is a significant difference between the regions in terms of government capital proportion to working capital. This proves hypothesis $\mathrm{H}_{4}$.

In case of trained- untrained staff ratio the calculated value of $F$ (4.29) is greater than the tabulated value of $\mathrm{F}(2.45)$ at 5\% level of significance and 5, 40 d.f., therefore, a significant 
difference between the regions in terms of trained-untrained staff ratio exists. This proves hypothesis $\mathrm{H}_{5}$.

The calculated value of $\mathrm{F}$ (0.94) for real growth rates at constant prices is less than the tabulated value of $\mathrm{F}$ (2.45) at 5\% level of significance and 5, 40 d.f., so, it is concluded that there is no significant difference between the regions in terms of real growth rates. Hence, it rejects $\mathrm{H}_{6}$ hypothesis.

The calculated value of F (159.547) for average member per society is greater than the tabulated value of $\mathrm{F}$ (2.45) at 5\% level of significance and 5, 40 d.f., hence, we can draw the inferences that there is a significant difference between the regions in terms of average member per society. This proves the hypothesis $\mathrm{H}_{7}$.

Now, we explain whether above factors have any impact on recovery performance or not, for which we consider average of 9 years data of each factor.

\section{Table 4: Correlations Matrix}

\begin{tabular}{|c|c|c|c|c|c|c|c|}
\hline & & 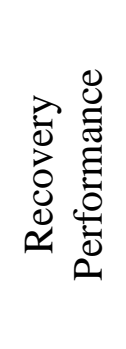 & 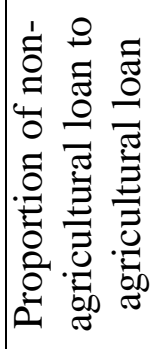 & 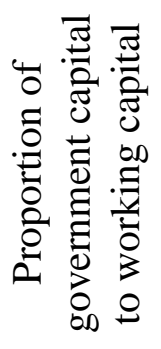 & 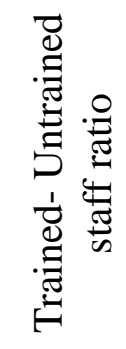 & 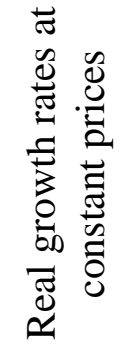 & 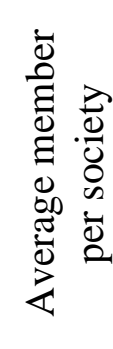 \\
\hline \multirow{6}{*}{ 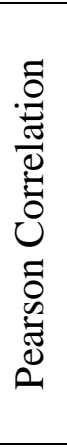 } & Recovery Performance & 1.000 & 0.352 & -0.733 & 0.764 & -0.158 & 0.505 \\
\hline & $\begin{array}{l}\text { Proportion of non-agricultural } \\
\text { loan to agricultural loan }\end{array}$ & 0.352 & 1.000 & -0.307 & 0.741 & 0.076 & 0.887 \\
\hline & $\begin{array}{l}\text { Proportion of government } \\
\text { capital to working capital }\end{array}$ & -0.733 & -0.307 & 1.000 & -0.800 & -0.546 & -0.183 \\
\hline & Trained- Untrained staff ratio & 0.764 & 0.741 & -0.800 & 1.000 & 0.257 & 0.605 \\
\hline & $\begin{array}{l}\text { Real growth rates at constant } \\
\text { prices }\end{array}$ & -0.158 & 0.076 & -0.546 & 0.257 & 1.000 & -0.291 \\
\hline & Average member per society & 0.505 & 0.887 & -0.183 & 0.605 & -0.291 & 1.000 \\
\hline \multirow{4}{*}{ 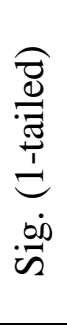 } & Recovery Performance & . & 0.247 & 0.049 & 0.038 & 0.382 & 0.154 \\
\hline & $\begin{array}{l}\text { Proportion of non-agricultural } \\
\text { loan to agricultural loan }\end{array}$ & 0.247 & . & 0.277 & 0.046 & 0.443 & 0.009 \\
\hline & $\begin{array}{l}\text { Proportion of government } \\
\text { capital to working capital }\end{array}$ & 0.049 & 0.277 & . & 0.028 & 0.131 & 0.364 \\
\hline & Trained- Untrained staff ratio & 0.038 & 0.046 & 0.028 & & 0.311 & 0.102 \\
\hline
\end{tabular}




\begin{tabular}{|l|l|c|c|c|c|c|c|}
\hline & $\begin{array}{l}\text { Real growth rates at constant } \\
\text { prices }\end{array}$ & 0.382 & 0.443 & 0.131 & 0.311 & $\cdot$ & 0.288 \\
\cline { 2 - 7 } & Average member per society & 0.154 & 0.009 & 0.364 & 0.102 & 0.288 &. \\
\hline
\end{tabular}

Source: Author's calculation

Part and partial correlation matrix is useful in understanding the relationship between the independent and dependent variables. The regression analysis is not valid if the independent and dependent variables are interrelated. This is known as multicollinearity. The above correlation matrix is useful in checking the inter relationships between the independent variables. In the above table, the correlations in square are correlation of independent variables with dependent variables and are high (-0.733, 0.764 and 0.505$)$ which means that the three variables are related. On the other hand, correlations between the independent variables $(0.741,0.887,-0.800,-0.546$ and 0.605) are high which means this data may have multicollinearity.

Table 5: Average Value of Five Factors in Six Regions

\begin{tabular}{|l|c|c|c|c|c|}
\hline Region & $\begin{array}{c}\text { Proportion of } \\
\text { non-agricultural } \\
\text { loan to } \\
\text { agricultural loan }\end{array}$ & $\begin{array}{c}\text { Proportion } \\
\text { of } \\
\text { government } \\
\text { capital to } \\
\text { working } \\
\text { capital }\end{array}$ & $\begin{array}{c}\text { Trained- } \\
\text { Untrained } \\
\text { staff ratio }\end{array}$ & $\begin{array}{c}\text { Real growth } \\
\text { rates at } \\
\text { constant } \\
\text { prices }\end{array}$ & $\begin{array}{c}\text { Average } \\
\text { member per } \\
\text { society }\end{array}$ \\
\hline Central & 6.62 & 1.86 & 55.24 & 8.14 & 0.62 \\
\hline Eastern & 9.52 & 1.70 & 49.79 & 7.91 & 1.66 \\
\hline Northern & 7.51 & 0.79 & 73.53 & 7.93 & 0.98 \\
\hline North- & 12.72 & 5.74 & 31.66 & 7.73 & 1.08 \\
\hline East & 68.68 & 0.49 & 96.53 & 8.19 & 3.28 \\
\hline Southern & 17.40 & 0.17 & 65.48 & 9.64 & 0.51 \\
\hline Western & & & & & \\
\hline
\end{tabular}

Source: Author's calculation

In Table 5, the mean value of five factors in six regions has been reflected. The proportion of non-agricultural loan to agricultural loan in southern region (68.68) is highest, whereas in central 
region it is lowest amount (6.62). Southern region shows steady upward recovery performance over the years. Hence, it can be stated that recovery performance is not inversely related to proportion of non-agricultural loan to agricultural loan. In Table 4, Pearson's correlation coefficient between these two variables is $0.352>0$. The variable, proportion of non-agricultural loan to agricultural loan is insignificant because $p>0.05$ (1-tailed test at 5\% level of significance). The amount of average contribution of government capital proportion to working capital in north-east region (5.74) is highest whereas as per recover performance is concerned this region shows very poor performance. Therefore, it illustrates that there is a negative relationship between recovery performance and contribution of government capital proportion to working capital. The correlation matrix in Table 4 also shows the negative correlation coefficient $(-0.733)$ between these two variables. This variable is significant because $p<0.05$. North-East region is showing the lowest level of trained-untrained staff ratio (31.66) whereas southern region is holding the highest level (96.53). Hence, we may draw the inferences that the traineduntrained staff ratio is having the positive impact on recovery performance of credit. Correlation coefficient between these two variables is 0.764 and this variable is significant because $\mathrm{p}<0.05$. In case of real growth rates at constant prices, there is no such significant difference between the regions and also some regions (Northern and Southern) are showing good recovery performance even if the growth rate is lower than that of the other region (growth rate of Western region and Central region are 9.64 and 8.14 respectively). Table 4 also suggests that there is a negative correlation coefficient $(-0.158)$ between recovery performance and real growth rates at constant price. The later one is insignificant because $\mathrm{p}>0.05$. Average member per society is maximum in southern region (3.28) and minimum in western region (0.51). The correlation coefficient between average member per society and recovery performance of credit is positive (0.505), but the former one is insignificant at $5 \%$ level of significance.

\section{Summary and Policy Implication}

The present study evaluates the agricultural credit recovery performance of PACS in six regions in India. The paper delineates some important results on which appropriate agricultural lending policy can be designed by the policy planners. The performance of credit recovery has been low in north-eastern states and high in northern and southern states. From 2002-2003 till 2010-2011 southern region has shown steady and upward progress in recovery performance, whereas, north- 
east region was having steady performance till 2007-2008, but after that there is a sharp fall in the next three years. The standard deviation and coefficient of variation is also higher than other regional states. So, the degree of variability or inconsistency level in terms of recovery performance is also very high. Recovery performance of credit is directly proportional to nonagricultural loan to agricultural loan, trained- untrained staff ratio and average member per society and inversely related with proportion of government capital to working capital and real growth rates at constant price. To make all PACS viable and ensure adequate and timely flow of cooperative credit to the rural areas, the Reserve Bank of India in collaboration with State Governments have been taking a series of steps to strengthen PACS and correct regional imbalances in cooperative development. Government role on providing larger funds to weak societies to write off their losses, bad debts and overdue intensify the poor recovery performance. The coordination must exist between the PACS and the branches of commercial banks in rural areas so that banks can assist such of those members of the PACS who are eligible for loans but are unable to get finance from PACS for lack of funds. They can also help the PACS with advice on proper maintenance of books of accounts, accounting procedures etc.

Finally it is said that although the PACS has continued to remain the weakest link in the entire cooperative structure yet it has a great importance for supplying the considerable amount of finances to the farmers at grass root level. 


\section{References}

Agarwal, K.P., Puhazhendhi, V., and Satyasai, K.J.S. (1997). “Gearing Rural Credit for the Twenty-First Century,” Economic and Political Weekly, October 18-24, p.2723.

Dandekar, V. M. and Wadia, F. K. (1989). "Development of Institutional Finance for Agriculture in India,” Journal of Indian School of Political Economy, Volume 1, No. 2, JulyDecember, p. 201.

Dongre, Y.Narayana Swamy, N. V.(1999). "Performance Evaluation Model for Primary Agricultural Credit Societies” Vikalpa, Volume 24, Number 1, January - March, pp.4553.

Government of India, Office of the Registrar General and Census Commissioner, India, http://www.censusindia.gov.in/vital_statistics/SRS_Reports.html, accessed on June 1, 2013.

Memane, A. S (2012). "Performance of Primary Agriculture Co-operative Societies during 200001 to 2009-10 in India.” Online International Interdisciplinary Research Journal, Volume 2, Issue 2, March-April, pp. 253-261.

Mishra, B.S. (2009). "Research on Performance of Credit Cooperatives." Research World, Volume 6, Article S6.5

Reserve Bank of India (2002). Trend and Progress of Banking in India, 2002, Table III. 10 and III. 11, para 3.39 and 3.40 .

Satyasai, K.J.S., and Badatya, K. C. (2000). "Restructuring Rural Credit Cooperative Institutions”, Economic and Political Weekly, January 29-February 4, p. 321.

Thirupathi, T. (2013). “An Analysis of Financial Performance of Select Primary Agricultural Cooperative Credit Societies In Mettur Taluk, Salem District.” Research Front, Volume 1, Number. 1, March, pp. 19-24.

Velayudham, T. K., and Sankarnarayanan, V. (1990). "Regional Rural Banks and Rural Credit: Some Issues,” Economic and Political Weekly, September 22, p. 2159. 